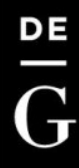

DOI 10.2478/pesd-2014-0020

PESD, VOL. 8, no. 1, 2014

\title{
MANAGEMENT OF ANTHROPOGENIC FACTOR IN MUREŞ COUNTY FORESTS
}

\author{
Ilie Covrig ${ }^{1}$, Valentin Năstăsescu
}

Keywords: anthropogenic influence, illegal felling, forest planning

\begin{abstract}
The analysis and drafting of a conclusion regarding the current state of the anthropogenic influence on the forests were conducted by the study of forest planning and other documents that serve the purpose of the research. By following the paths in the forests of Mureş county, several remarks were noted on the state of private and state-owned forest areas: the forester's intervention in the woods, in terms of the application of silvicultural treatments and forest regeneration and promotion of the basic natural type of forest, the mapping of anthropogenically damaged areas, remarks on the planning of guarding activities and preventing illegal actions in the woods. The actions that cause damage to the forest and the general stock of wood are identified especially in terms of illegal felling. The damages caused though illegal felling during the analyzed period (1970 - 2013), enable us to assert that this kind of damages were recorded throughout the entire analyzed interval. The causes determining a high anthropogenic pressure on the forests are easily identified by the legislative gaps, social poverty of the Romanian society, the influence of the political factor on the national forest strategy, impairment of the forester's authority in the forests, the dependence of local communities to the forests etc. All these require identification of immediate solutions for the recovery of the anthropogenically damaged areas by afforestation, provision of a sole, coherent and efficient legislative framework, approach of a new concept in terms of supervision and control in the forests.
\end{abstract}

\section{Introduction}

The current economic and social situation requires the timely solution, respectively theoretical and practical clarification of the shortcomings generated by the anthropogenic impact on the natural ecosystems, especially on the forest ecosystems $[3,4,5,6]$.

\footnotetext{
${ }^{1}$ Mureş Forestry Department, ilie_covrig@yahoo.com, valentinnastasescu@yahoo.com
} 
Of all the disturbing factors, one concludes that the human factor, by his activities and measures, induces effects on the forest ecosystems both at local, regional, national and global level $[4,5,6,7,8,9]$.

There is an objective, direct relation between the economic and ecological processes $[1,2,4,5,7,8,9]$. The relation between the economic processes and wise management of ecosystems' natural resources should be in a permanent balance $[5,6,7]$. The identification of the carrying limit of the natural forest ecosystems with the economic and social ones determines the needs - resources balance $[5,7,8,9]$.

The natural ecosystems, especially the forest ecosystems create the necessary conditions for the social system development. Human society in relation with the social system as a whole may sometimes irreversibly affect and alter the forest systems self-regulation $[3,5,6,7,8,9]$.

The analysis of anthropogenic factor management is relevant at administrative unit level, relatively homogenous in terms of geographical characteristics, tree structure, wood products demand, forest-dependent local communities, level of local economic and social development and the comparison with those at national level $[5,7,8,9]$.

The purpose of the research is to contribute with scientifically-substantiated original elements to the general knowledge of the anthropogenic impact on the forest vegetation in Mureş county and to bring both theoretical and practical contributions for the prevention and control of illegal activities in the forests, as well as proposal of measures regarding the rehabilitation of anthropogenically damaged forest ecosystems.

The main objective of this research paper is to assess the consequences of the anthropogenic factor impact and the disturbances caused by this factor in the forest ecosystems from Mureş county.

The specific objectives include: identification and mapping of anthropogenically damaged areas; the inventory of resources and data regarding the current situation of the studied area, types of brush, development conditions, types of property and administration; determination of the work method, materials and necessary equipment; analysis of all elements and data regarding the resources; proposal of measures regarding the human action impact mitigation; monitoring and assessment of the measures proposed for the remediation of anthropogenic effects.

\section{Materials and methods}

In order to identify and characterize the current situation regarding the quantitative assessment of anthropogenic influence, relevant findings were 
considered in terms of the damages generated by the creation of structural imbalances of brushes, both vertically and horizontally, damages caused by illegal felling, seeding and soil, as well as the disturbances produced to forest biocenose and biodiversity conservation.

In order to conduct the researches, the following targets were set:

- identification and assessment of the disruptive and damaging impact on the forests in the entire research area (within the forest district, but also in the forest areas which are not managed, passed on by property restitution), according to the illegal felling and wood theft criteria;

- identification and recording of all changes inferred to forest ecosystems;

- conduct of dendrometric measurements in order to quantify the damages caused to forests in terms of illegally cut volumes and to compare the resulting volumes to the provisions of the previous planning activities;

The data included in the paper originate from documents drafted by the authors and by the staff of the forest districts, measured in the field, but also by comparing the data with the provisions of the previous planning activities regarding the clear-cut areas, cleared of timber from the private not managed forests by forest structures, both regarding the assessment of the total wood volume, species and wood varieties.

\section{Results and discussions}

The area covered by the forest vegetation in the Mureş county, in 2012 totals 217,679 hectares. Forest management is conducted by the Mureş Forestry Department $\mathrm{Tg}$. Mureş through 10 forest districts, managing 105.4 thousand hectares of state-owned forests and 70.4 thousand hectares of private forests, representing $80 \%$ of the forest area of the county.

Another 38.5 thousand hectares forest area is managed by 4 forest districts representing $17.6 \%$. One may thus notice that the 3.3 thousand hectares area extended throughout the county are not managed by an authorized forest structure, especially the areas retroceded as per Law 18/1991.

Of all the factors causing the disturbance of the forest ecosystem (which led invariably to the increase of anthropogenic impact), illegal felling especially in private forest is the most severe and disturbing.

The mapping of brushes exposed to the anthropogenic factor was developed depending on the consistence parameter. There were identified some lands severely damaged by the anthropogenic factor, by the incorrect implementation of silvicultural treatments, application of shallow inaccurate studies regarding the forests (age, composition, and consistence), and increase of selective illegal felling. 
The brushes cleared of timber with a 0.1-0.4 consistence were also included in the category of severely damaged lands.

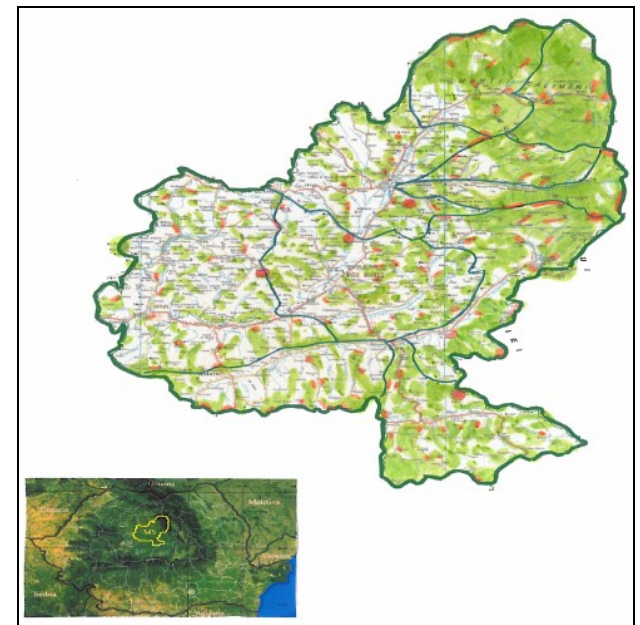

Fig.1 Location and mapping of risk areas anthropogenically affected in the study area, Mureş county, Romania (Source: ro.wikipedia.org, Mures Forestry Department, private forest districts)

As one may notice in figure 1, during the 1990 - 2012 period, the mountainous area was damaged by the anthropogenic factor in the localities Stânceni, Lunca Bradului and Răstolița. The hill and plain area is mainly affected near the localities where numerous unemployed rroma citizens live, in the following localities: Petelea, Tonci, Glodeni, Band, Tg. Mureş, Boiu, etc.

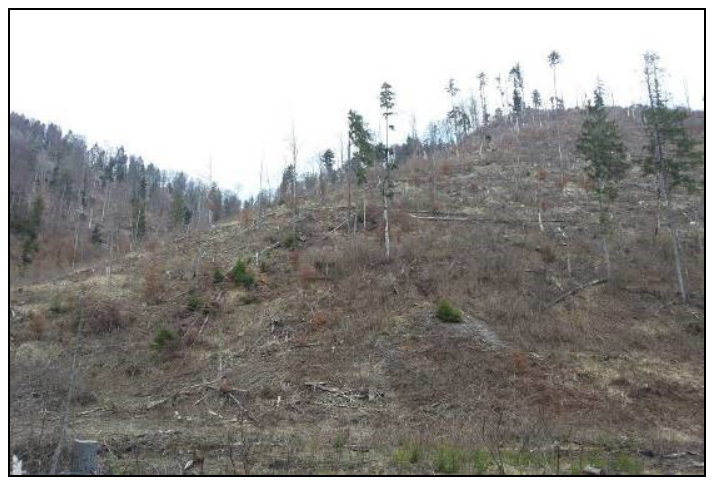

Fig. 2 Deforestation of private forest areas -Stânceni- Zebrac in 2012 
The state-owned forest areas and those managed by authorized forest structures were affected by illegal felling below the disrupting level of tree stability, included in the slightly damaged category, although in time there were numerous variations caused mainly by the social factors.
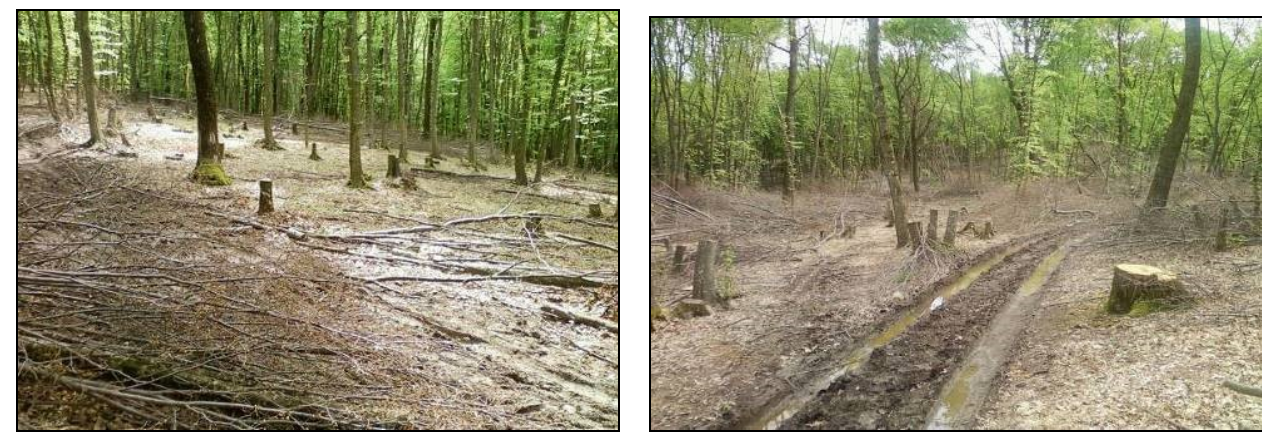

Fig. 3 Deforestation of private forest areas -Petelea in 2009

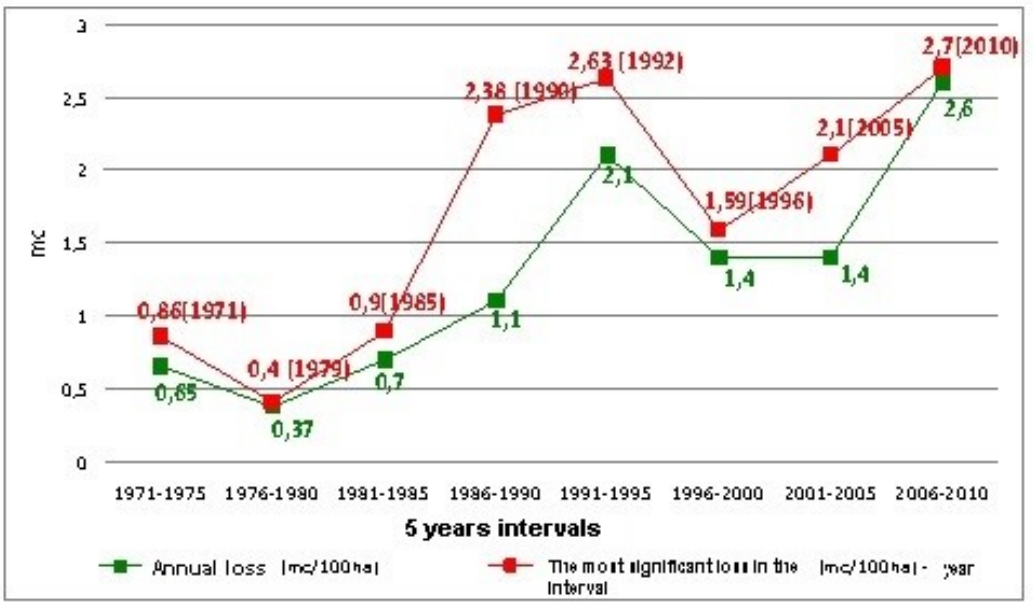

Fig. 4 Dynamics of damages found in illegal cutting of trees in state-owned and private property forests, managed by state forest structures (volume/ $100 \mathrm{ha}$ ),

1970 - 2010 (Source: Mures Forestry Department, private forest districts)

The analysis of the results achieved after conducting the research, as illustrated in figure 4, identifies the evolution of damages since the foundation of Mureş county. The damages caused to the forest by illegal felling during the analyzed time interval enable us to claim that the damages were recorded throughout the entire period. 
The damages have been analyzed on five years intervals expressed in $\mathrm{m}^{3} / 100$ ha, enabling us to conduct a careful and accurate analysis of the damages caused before and after 1990, until 2010. The control interval considered in this paper was the 1970 - 1990 period, since the founding of the Mureş county until 1990, when the forests were entirely state-owned, with administration and guard provided by the forest department staff.

One could notice that during the 1970 - 1990 period, the wood volume of illegal felling reached the maximum value in the $1986-1990$ interval, i.e. $1.1 \mathrm{~m}^{3} /$ 100 ha, followed by the $1981-1985$ interval, i.e. $0.7 \mathrm{~m}^{3} / 100$ ha, the $1970-1975$ interval with $0.65 \mathrm{~m}^{3} / 100 \mathrm{ha}$, respectively, the $1976-1980$ interval with $0.37 \mathrm{~m}^{3}$ / 100 ha.

The highest damage during this period was recorded in the year 1990, i.e. 2.38 $\mathrm{m}^{3} / 100$ ha.

The $1991-2010$ interval has a special characteristic. As a result of property restitution, large damages were noticed especially during the $1991-1995$ period, when the loss reached $2.1 \mathrm{~m}^{3} / 100$ ha, followed by a decrease to $1.4 \mathrm{~m}^{3} / 100$ ha during the 1996 - 2000 period.

After a period of apparent stability and damage mitigation in 2000- 2005, starting with the year 2006 the property restitution process continued, which resulted again in the increase of damages to $2.6 \mathrm{~m}^{3} / 100$ ha throughout the entire period, until 2010, inclusively.

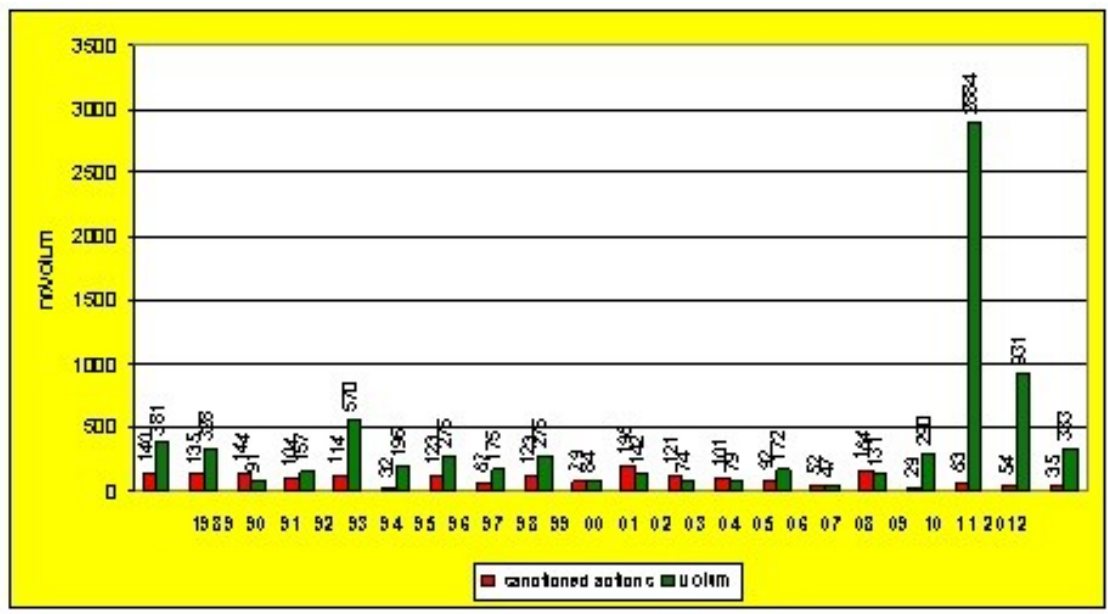

Fig. 5 Situation of findings and damages to exploitation irregularities - stateowned forests, managed by state forest structures 1989 - 2012(Source: Mures Forestry Department, private forest districts) 
Referring to the years when the highest damages were caused, after 1990, the year 1992 stands out with $2.63 \mathrm{mc} / 100 \mathrm{ha}$, followed by the year $2010-2.7 \mathrm{~m}^{3}$ / 100 ha.

At the same time, the lowest damages were noticed during the $1971-1975$ interval with $0.65 \mathrm{~m}^{3} / 100 \mathrm{ha}$, the $1976-1980$ interval with $0.37 \mathrm{~m}^{3} / 100$ ha and the 1981 - 1985 interval with $0.7 \mathrm{~m}^{3} / 100$ ha. The lowest damage was recorded in 1980 , with a volume of $0.3 \mathrm{~m}^{3} / 100$ ha.

Considering the statistic data on the standard of living in Romania, one may conclude that there is a close connection between poverty, dependence on forests and anthropogenic pressure.

The highest damages were recorded in the 1991-1995 $\left(2.1 \mathrm{~m}^{3} / 100 \mathrm{ha}\right)$ and $2006-2010\left(2.6 \mathrm{~m}^{3} / 100 \mathrm{ha}\right)$ intervals, explained by the poor legislation regarding forest management, and by the illegal felling from private forests, retroceded as a result of property restitution on the forest lands and on the areas that were not managed in terms of forest, as well as by the non-observance of the forest exploitation regulation (by the access the economic operators in the forests).

After 1990, the damages identified are significantly higher than the average value of the 1970-1990 interval and are rather constant and ascendant during the entire $2006-2010$ period, explained especially by the irregularities identified in wood exploitation from authorized felling areas (fig.5).

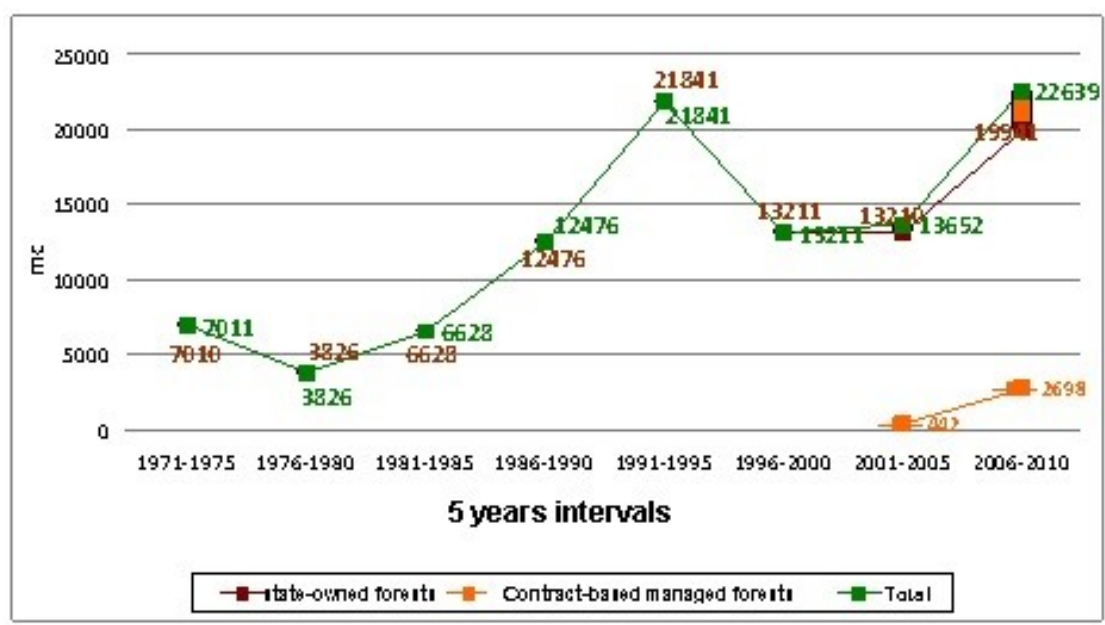

Fig. 6 Dynamics of illegal felling of timber from state-owned and private forests, managed by state forest structures (thousand $\mathrm{m}^{3}$ ), $1970-2010$

(Source: Mures Forestry Department, private forest districts) 
The detailed analysis on the illegally cut wood volume (thousand of cubic meters during the five years interval) enables the identification of some relevant aspects in the analysis of this phenomenon.

Certainly, illegal felling existed during the entire time period considered, but their intensity obviously differs, from a five years period to another fig.6.

The comparative data analysis regarding the $1970-1990$ control interval characterised by the centralized communist economic system, all the other options, with few exceptions, present significant to very significant diversions. After 1970, during a five years interval, 1986 - 1990, illegal felling was significantly higher than that of the control period. The other five years intervals are either identical with the control period in terms of illegal felling volume, or significantly lower than the control value.

One remark is necessary for the intervals after 1990 when all the five years intervals record significant differences higher than the 1970 - 1990 interval, considered as a control interval. It is obvious that at least the first five years interval (1991 - 1995) presented a unique increase of the illegal felling volume, reaching $21,841 \mathrm{~m}^{3}$, with $15,213 \mathrm{~m}^{3}$ more than in the $1985-1990$ interval. Although during the 1996- 2005 period, the illegally felling wood volume has decreased, it remained relatively constant at $13,211 \mathrm{~m}^{3}$, respectively $13,656 \mathrm{~m}^{3}$ similar to the 1986-1990 interval. It is worth noting that during the last five years analyzed interval (2006 - 2010), a significant increase of the illegal felling wood material was recorded, reaching $22,639 \mathrm{~m}^{3}$, above the differences significance limit.

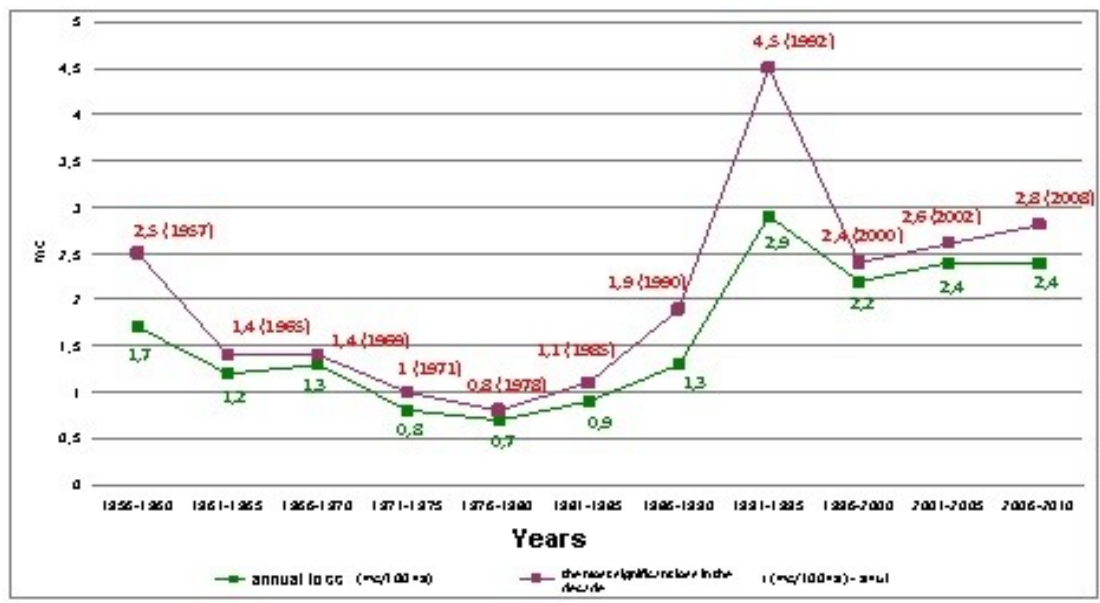

Fig. 7 Dynamics of loss caused by illegal felling in state-owned and private forests, managed by state forest structures (volume/100 ha), in Romania, 1956- 2010 [7] 
The effects analysis of the anthropogenic factor in Mureş county is similar to the national state of things, according to Figs. 7 and 8, by comparison, with few exceptions.

One may conclude that the measures applied lately in the management of state-owned and private forests do not meet the current requirements in terms of prevention of criminal activities in the forest and cease of illegal felling.

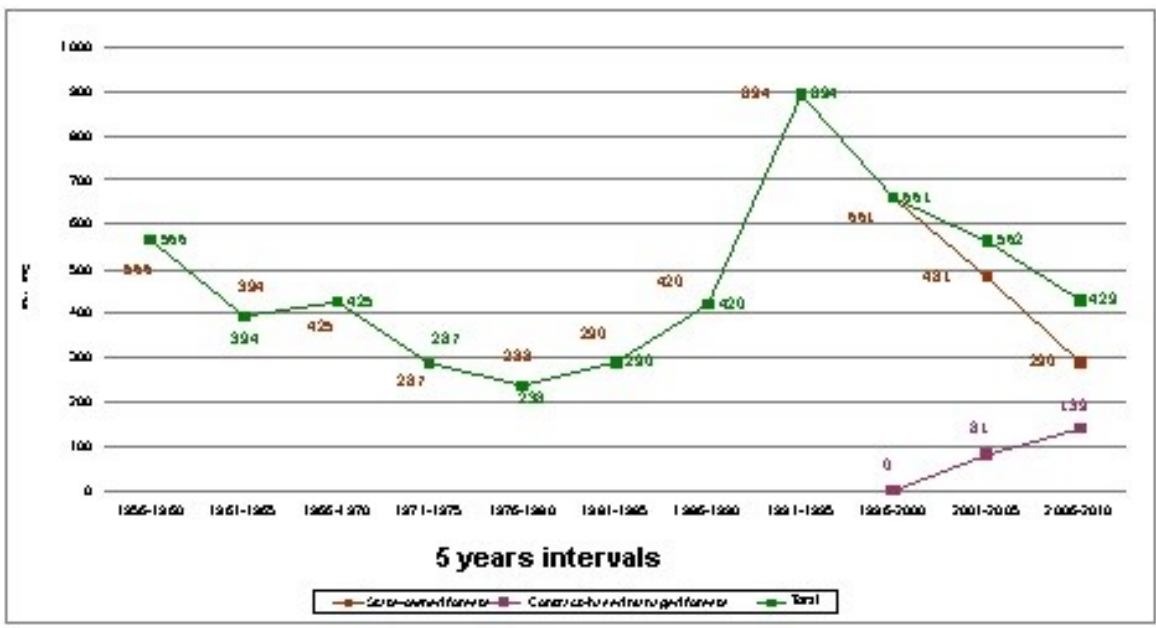

Fig. 8 Dynamics of illegal felling of wood material from state-owned and private forests, managed by state forest structures (thousand $\mathrm{m}^{3}$ ), in Romania, 1956- 2010 [7]

The reality regarding the anthropogenic impact in Mureş county does not include all the damages in the forests, because there is a large illegally cut and stolen wood volume in the private forests not managed in terms of forest planning, where the control of national forest authorities was not performed.

Another aspect that should not be neglected is the deforestation of the forest vegetation from the pasture areas that were afforested after 1990, much of these in an advanced degree of degradation.

Although the animal stock did not spectacularly grow, in order to benefit of the amounts allotted by the state and the European Union as subsidies by the APIA programme, numerous owners lease the lands to "support themselves", thus deforesting the vegetation installed in 20 years. In most of the cases, the composition and consistence of the forest is brush, which can be included from the pastures category of use to that of forests. 


\section{Conclusions}

The assessment of the damages caused to forests by the increase of the anthropogenic factor intensity is materialized by the social and economic pressure of the forest-dependent local communities.

Of all the analyzed factors regarding the anthropogenic impact on the forest ecosystem, the illegal felling in private forests not managed in terms of forest planning was considered to be the most disturbing.

The significant anthropogenic impact identified by illegal felling in the research areas were favoured also by accessibility, the relatively short distances to the chipping machines, the gaps of the legislative framework, the fact that in the respective areas the forests were not properly managed.

The large wood volume identified as illegally cut in the currently exploited felling areas was determined as a result of the multinational corporation that buy good quality wood, the pine wood low quantity, the high standing timber price, and the reduced economic power of local economic operators.

The repeated anthropogenic intervention in the forest areas impacted by illegal felling prevents natural regeneration and restoration of forest ecosystems.

\section{Recommendations}

Considering the results of the paper and the conclusions drawn above, the following recommendations can be drafted:

- reduction of the cutting rate in the bordering anthropogenically affected areas;

- rehabilitation of the forest ecosystems by the afforestation of the clear-cut areas, rehabilitation of the brushes by the promotion of the natural basic type of forest;

- reconsideration and division of the respective brush in special protection functional groups;

- the correct assessment and quantification of the social and economic function of the forest;

- identification of solutions regarding the promotion of a new Forest Code Lex ferenda, developed by forest and juridical specialists, which will include new solutions regarding all the aspects related to the forest domain, including clearly drafted norms and technical guidance, etc., to consider among others:

- comprehension of European provisions in the national regulations, applying the sustainable forest management concept;

- disambiguation of responsibilities and implementation of the forest district territoriality principle in developing the forest department; 
- unitary management of all forest areas regardless of the property structure by means of the forest districts;

- unitary management of all forest areas in production units;

- initiation of regulations in application of silvicultural treatments to pursue mainly what remains in the forest (the trees) plus / minus what leaves the forest;

- the implementation of law on the afforested pasture areas and their inclusion in the national forest fund, as well as the interdiction to deforest them under the pretext of clearing the pasture;

- reconsideration of the surveillance and guard activity in the forest by specialized personnel, adoption of a new concept regarding the guard activity based on the personnel training and responsibility;

- drafting of a control regulation of the wood material traffic, provision of marked company cars and equipped with acoustic and green light signals, etc;

- identification of infringement solutions related to the provisions of the Criminal Code regarding illegal felling activities and wood theft from national forests;

- initiation of an efficient system for the assessment, use and rigorous management of the wood resources by the forest administrator;

- identification of solutions regarding the protection of the foresters for the sustainable development of forests.

The paper represents a benchmark for the state institutions designated to manage the forests, respectively to determine a more realistic actions on the forest conducted to an equal extent by forest administrators, technical experts and owners.

However, the results of this paper are extremely useful to the scientific community regarding the consequence analysis of the irresponsible human action on the forests.

\section{References}

[1] Bouriaud, Laura, 2002, Forest Law - Forestry Legislation, Ed. Universităţii, Suceava [in Romanian];

[2] Ene, C., Vlad, C., 2006, Forestry offences - Theory and Judicial Practice, Ed. C.H.Beak Bucharest [in Romanian];

[3] Florescu, Gh., Nicolăiescu, N.V., 1998, Silviculture, vol. II, Silvotehnică, Ed. Universităţii Transilvania din Braşov [in Romanian];

[4] Giurgiu, V., ş.a.,1995, Protejarea şi dezvoltarea durabilă a pădurilor României, Ed. Arta Grafică, Progresul Silvic, Bucharest [in Romanian];

[5] Giurgiu, V., 2004, The Sustainable Management of the Romanian Forests, Ed. Academiei Române [in Romanian];

[6] Machedon, I., 1996, The Protective Functions of the Forests - An Economic Assessment, Ed. Ceres, Bucharest [in Romanian]; 
[7] Năstăsescu, V.V., 2012, Research on the Identification, Quantification and Analysis of the Anthropogenic Factor on the Forest Vegetation in the Gurghiu Mountains, Ph.D. Thesis, University of Agronomic Sciences and Veterinary Medicine of Cluj-Napoca [in Romanian];

[8] Năstăsescu, V.V., Zaharia D., 2012, The Management of the Antropic Contribution to Forestry Ecosystem in Gurghiu Mountains, ProEnvironment, 5(9), pp.3-10;

[9] Năstăsescu, V.V., Zaharia D., 2012, Research Concerning the Phenotypical Variability of Spruce Trees within Recovered Forestry Areas during 1995-2005, from Gurghiu Mountains, ProEnviroment, 5(9), pp.11-18. 